\title{
Mites of the order Mesostigmata on plots reforested with Scots pine after various kinds of soil preparation and wood residue utilization after clear-cutting
}

\author{
MACIEJ SKORUPSKI ${ }^{1}$, ROMAN GORNOWICZ ${ }^{2}$, MARCIN SPAETH ${ }^{1}$ \\ and ANNA WIERZBICKA ${ }^{1}$ \\ ${ }^{1}$ Department of Game Management and Forest Protection \\ ${ }^{2}$ Department of Forest Technology \\ Poznań University of Life Sciences, ul. Wojska Polskiego 71d, 60-625 Poznań, Poland \\ Corresponding author: Maciej Skorupski, maskorup@up.poznan.pl
}

(Received on 15 June 2008; Accepted on 8 March 2011)

\begin{abstract}
The clear-cutting system is still popular, especially on poor sites in Central European forests. It causes serious disturbances in natural processes during forest regeneration. The main objective of this research on mesostigmatid mites was to evaluate and compare the influence of various kinds of soil preparation and treatment of the wood debris left after clear-cutting (on plots reforested with Scots pine Pinus sylvestris). As a result of the conducted investigations, 24 mite species of the order Mesostigmata were found. The highest number of species represented the families Parasitidae ( 7 species), Laelapidae (4 species) and Zerconidae, Digamasellidae, Ascidae (3 species each). The study was conducted on an experimental plot in the Międzychód Forest District (West Poland). The species composition of mite communities on all subplots is characteristic for Scots pine forests. The highest numbers of individuals and species were collected on the plots where the wood residue was burnt or chipped and left on the soil surface. The lowest numbers of individuals and species were colleted on the plots where the chipped wood residue was mixed with soil or removed from the plots. The method of wood residue utilization significantly influenced the community structure of the Mesostigmata, while various kinds of soil preparation before reforestation did not have any significant influence.
\end{abstract}

Key words: Scots pine, Pinus sylvestris, reforestation, mites, Acari, Mesostigmata, species composition

\section{INTRODUCTION}

Forest management in Poland and in Europe is based on the principle of sustainability, formulated in 1804 by L.G. Hartig. According to this principle, present generations of people should maintain the forests in the way that the benefits gained from the forests by future generations will not be lower than those currently achieved (GorNOwICZ 2005). Sustainability may be achieved only on the basis of ecology. The proper development of forests requires the cycling of nutrients and a continuous flow 
of energy between the trophic levels of a forest ecosystem. Therefore, one has to establish what benefits may be gained from a forest so that the habitat will not suffer (e.g. due to soil acidification or loss of nutrients). A good way to maintain forest soil fertility is to leave wood debris (residue) at clear-cut sites, as the residue contains many minerals, which return to the soil, facilitate the decay of duff, and prevent the creation of acid humus (GoRNOwICZ 2005). It is therefore worthwhile to find out which wood residue utilization methods have a positive influence on the soil, and the qualities of clear-cut sites. The soil fauna seems to be a good indicator of fertility and other natural qualities, as such organisms react to the changing environment relatively fast.

This research aimed at establishing which method of wood residue utilization and soil preparation provides best conditions for the soil fauna after a clear-cut and artificial reforestation, being a huge change in the local environment.

\section{MATERIALS AND METHODS}

The experimental plot of the Department of Forest Technology is situated in the Międzychód Forest Division (area 194d). It lies in the Noteć Forest (Puszcza Notecka), which is the largest compact forest complex in the Wielkopolska Lowland and the second largest in Poland $\left(1200 \mathrm{~km}^{2}\right)$. The forest grows on inland dunes $(20-30 \mathrm{~m}$ high). Taking into account the Polish climate in general, the local climate is relatively warm and dry, with an average precipitation of 535-570 mm (KUSIAK \& DYMEK-KUSIAK 2002) and annual average temperature of $7.8-8.1^{\circ} \mathrm{C}$ (Woś 1994).

On the 3.3-ha plot, Scots pine Pinus sylvestris L. is grown on a potential site of fresh coniferous forest (labelled by Polish foresters as Bśw), on a deluvial soil formed on loose dune sand. In the spring of 2001, Scots pine (80\%) and birch Betula pendula L. (20\%) was planted in the plot, in the form of strips and clumps. In addition, grey alder Alnus incana (L.) Moench was planted between rows to improve the productivity of the soil. Grey alder is known to enrich the soil with nitrogen thanks to actinomycetes (symbiotic bacteria from the order Actinomycetales, now classified as the type Actinobacteria). This is especially advantageous in the poor soil of the plot.

The plot was divided into 3 belts ( $18 \mathrm{~m}$ wide, $600 \mathrm{~m}$ long), each with a different soil preparation method (A, B and $\mathrm{C}$ ), in the north-south direction:

$\mathrm{A}=$ furrows with a ditch (the eastern belt, adjoining a young forest stand): furrows were ploughed with an active single-disc forest plough U-162 with a subsoiler, fixed to a tractor);

$\mathrm{B}=$ no preparation (the central belt);

$\mathrm{C}=$ classic furrows (the western belt, adjoining a 100-year-old forest): the soil was prepared by ploughing furrows with a double-mouldboard plough Lpz-75 with a ripper, used most often in forest sites.

The 3 differently prepared belts (basic belts) were divided by 5 transverse belts into 5 subplots in each basic belt. The transverse belts were subjected to various methods of wood residue utilization: $1=$ raked and removed; $2=$ burnt; $3=$ left 
undisturbed; 4 = chipped and left on the surface; $5=$ chipped and mixed with the soil.

Soil samples from each subplot were taken 3 times in November 2005 with a sampler of $40 \mathrm{~cm}^{2}$ (in total: 15 subplots and 45 soil samples). The samples were taken between trees, to the depth of $5 \mathrm{~cm}$ of mineral soil, together with litter and humus. The mites were extracted in Tullgren funnels. Permanent and fresh preparations were made.

The analysis of the results was conducted with the aid of the AnalizaTOR 2.0 software (Desmodus, Poland), using typical indices:

- $\quad$ species similarity between microhabitats $(S)$, calculated as $S=2 C /(A+B)$, where $A=$ number of species in one microhabitat; $\mathrm{B}=$ number of species in another microhabitat; and $C=$ number of species common to both microhabitats;

- dominance $(D$, in $\%)$, calculated as $D=s / S$, where: $s=$ number of individuals of a species; $S=$ number of individuals of all species recorded in the habitat (ODUM 1982).

The following dominance classes were distinguished: eudominants $(>10 \%)$, dominants $(5.1-10 \%)$, subdominants $(2.1-5.0 \%)$, recedents $(1.1-2.0 \%)$, subrecedents $(<1.1 \%)$ (NiedBAŁA et al. 1981). Also a multivariate analysis of variance (MANOVA) was conducted with the aid of SAS 9.1.3 software, to establish whether wood residue utilization and soil preparation methods have a significant influence on the number of mite individuals and species per sample.

The species names and taxonomy of Mesostigmata are consistent with BŁASZAK \& MADEJ (1997) and WiŚNIEWSKI (1997).

\section{RESULTS AND DISCUSSION}

A total of 1724 mites from the order Mesostigmata were collected. They represent 26 mite taxa of 10 families, of which 21 were identified to the species level and the others were identified to the genus level. The family Parasitidae was represented by 6 species, the Laelapidae by 4, while the Zerconidae, Digamasellidae and Ascidae by 3 species each. The species composition in all subplots was typical for pine forests growing on fresh coniferous forest sites (SKORUPSKI \& BŁASZCZAK 1998). The list of Mesostigmata recorded in each of the differently prepared basic belts and their dominance indices are presented in Table 1 . In all the differently prepared basic belts, eudominants include Paragamasus conus (Karg, 1971) and Gamasellodes bicolor (Berlese, 1918), whereas dominants are Zercon zelawaiensis (Sellnick, 1944) (only on belt A as a eudominant) and Asca aphidiodes (Linnaeus, 1758) (only on belt A as a recedent), Paragamasus vagabundus (Karg, 1968) (on belt C) and Amblyseius sp. (on belt A). The list of Mesostigmata mites recorded on transverse belts (different wood residue utilization methods), and their dominance indices are presented in Table 2. The dominant species in all transverse belts are Paragamasus conus and Gamasellodes bicolor, but their dominance in individual subplots varied widely, from 12.3 to 40.54 for Paragamasus conus and from 22.58 to 60.43 for Gamasellodes bicolor. Eudominants included also Paragamasus vagabundus (belt 1) and Zercon zelawaiensis 
Table 1. Dominance index (\%) of mesostigmatid mites found in differently prepared basic belts ( $\mathrm{A}=$ furrow with a ditch; $\mathrm{B}=$ no preparation; $\mathrm{C}=$ classic furrow)

\begin{tabular}{|c|c|c|c|}
\hline \multirow{2}{*}{ Species } & \multicolumn{3}{|c|}{ Dominance index (\%) } \\
\hline & belt A & belt B & belt $\mathrm{C}$ \\
\hline Amblyseius sp. & 8.11 & 2.53 & 3.35 \\
\hline Anthoseius sp. & 0 & 0 & 0.15 \\
\hline Asca aphidioides (Linnaeus, 1758) & 1.69 & 6.53 & 5.78 \\
\hline Asca bicornis (Canestrini \& Fanzago, 1887) & 1.52 & 0 & 4.87 \\
\hline Dendrolaelaps foveolatus (Leitner, 1949) & 0.34 & 0 & 0 \\
\hline Dendrolaelaps latior (Leitner, 1949) & 2.36 & 3.16 & 0.91 \\
\hline Dendrolaelasp sp. & 1.01 & 0 & 0.15 \\
\hline Gamasellodes bicolor (Berlese, 1918) & 38.68 & 29.26 & 31.2 \\
\hline Hypoaspis aculeifer (Canestrini, 1883) & 1.01 & 2.32 & 0.76 \\
\hline Hypoaspis karawaiewi Berlese, 1903 & 1.35 & 1.89 & 0 \\
\hline Hypoaspis lasiomyrmecophilus Hirschmann, 1969 & 0 & 0 & 0.46 \\
\hline Hypoaspis praesternalis Willmann, 1949 & 0.17 & 1.68 & 0.15 \\
\hline Leptogamasus tectygynellus Athias-Henriot, 1967 & 0.84 & 4.63 & 1.83 \\
\hline Paragamasus conus (Karg, 1971) & 25.34 & 30.11 & 34.4 \\
\hline Paragamasus sp. & 0 & 0 & 0.3 \\
\hline Paragamasus vagabundus (Karg, 1968) & 1.35 & 3.58 & 5.78 \\
\hline Parasitidae sp. & 0 & 0.21 & 0.3 \\
\hline Parazercon radiatus (Berlese, 1914) & 0 & 0.21 & 0.61 \\
\hline Pergamasus crassipes (Linnaeus, 1758) & 0 & 0.63 & 1.37 \\
\hline Pergamasus sp. & 0 & 0 & 0.15 \\
\hline Rhodacarus mandibularosimilis Shcherbak et Kadite, 1980 & 1.01 & 2.74 & 0.76 \\
\hline Trachytes aegrota (C.L.Koch, 1841) & 0.17 & 0.21 & 0 \\
\hline Trichouropoda ovalis (C.L. Koch, 1839) & 0.17 & 1.47 & 0.15 \\
\hline Veigaia cervus (Kramer, 1876) & 0 & 0.21 & 0.15 \\
\hline Veigaia nemorensis (C.L. Koch, 1839) & 0.84 & 1.89 & 0.3 \\
\hline Zercon peltatus C.L. Koch, 1836 & 0 & 0.42 & 0 \\
\hline Zercon zelawaiensis Sellnick, 1944 & 14.02 & 6.32 & 6.09 \\
\hline
\end{tabular}


Table 2. Dominance index (\%) of mesostigmatid mites found in transverse belts with different wood residue utilization methods $(1=$ raked and removed; $2=$ burnt; $3=$ left undisturbed; $4=$ chipped and left on the surface; $5=$ chipped and mixed with the soil)

\begin{tabular}{|c|c|c|c|c|c|}
\hline \multirow{2}{*}{ Species } & \multicolumn{5}{|c|}{ Dominance index (\%) } \\
\hline & belt 1 & belt 2 & belt 3 & belt 4 & belt 5 \\
\hline Amblyseius sp. & 5.35 & 3.29 & 0.79 & 7.94 & 6.01 \\
\hline Anthoseius sp. & 0 & 0 & 0 & 0 & 0.3 \\
\hline Asca aphidioides & 0 & 2.74 & 3.54 & 8.93 & 5.71 \\
\hline Asca bicornis & 0 & 6.03 & 1.57 & 0.99 & 0 \\
\hline Dendrolaelaps foveolatus & 0.53 & 0.18 & 0 & 0 & 0 \\
\hline Dendrolaelaps latior & 1.07 & 4.02 & 1.97 & 1.49 & 0 \\
\hline Dendrolaelasp sp & 0 & 0.18 & 2.36 & 0 & 0 \\
\hline Gamasellodes bicolor & 60.43 & 38.57 & 24.8 & 22.58 & 28.53 \\
\hline Hypoaspis aculeifer & 0.53 & 0.73 & 3.15 & 1.24 & 1.2 \\
\hline Hypoaspis karawaiewi & 0 & 0.37 & 2.36 & 0.5 & 2.1 \\
\hline Hypoaspis lasiomermecophilus & 1.6 & 0 & 0 & 0 & 0 \\
\hline Hypoaspis praesternalis & 0 & 0 & 0 & 2.23 & 0.3 \\
\hline Leptogamasus tectygynellus & 1.07 & 2.74 & 2.76 & 0.74 & 3.6 \\
\hline Paragamasus conus & 12.3 & 32.18 & 38.98 & 21.34 & 40.54 \\
\hline Paragamasus sp. & 0 & 0 & 0 & 0.5 & 0 \\
\hline Paragamasus vagabundus & 10.7 & 4.02 & 5.91 & 0.99 & 0.6 \\
\hline Parasitidae sp. & 0.53 & 0 & 0.39 & 0.25 & 0 \\
\hline Parazercon radiatus & 0.53 & 0.73 & 0 & 0 & 0 \\
\hline Pergamasus crassipes & 0 & 0.73 & 0.79 & 1.49 & 0 \\
\hline Pergamasus sp. & 0 & 0 & 0 & 0.25 & 0 \\
\hline Rhodacarus mandibularosimilis & 1.07 & 0 & 3.15 & 1.74 & 2.1 \\
\hline Trachytes aegrota & 0 & 0.18 & 0 & 0.25 & 0 \\
\hline Trichouropoda ovalis & 0 & 1.28 & 0.79 & 0 & 0 \\
\hline Veigaia cervus & 0.53 & 0 & 0 & 0 & 0.3 \\
\hline Veigaia nemorensis & 2.67 & 0.91 & 0.79 & 0.25 & 0.9 \\
\hline Zercon peltatus & 1.07 & 0 & 0 & 0 & 0 \\
\hline Zercon zelawaiensis & 0 & 1.1 & 5.91 & 26.3 & 7.81 \\
\hline
\end{tabular}


(belt 4). Dominants are represented by Asca aphidiodes (belts 4 and 5), Asca bicornis (Canestrini \& Fanzago, 1887) (belt 2), Amblyseius sp. (belts 1, 4 and 5), Paragamasus vagabundus (belt 3) and Zercon zelawaiensis (belts 3 and 5).

Very high similarity rates (74.58 and 83.42 ) of dominance indices of all mesostigmatid mite species in the basic belts indicate a low variation in community structure (Fig. 1). It is proved by statistical analysis: the average number of species (Table 3) and the average number of individuals (Table 4) do not differ significantly between

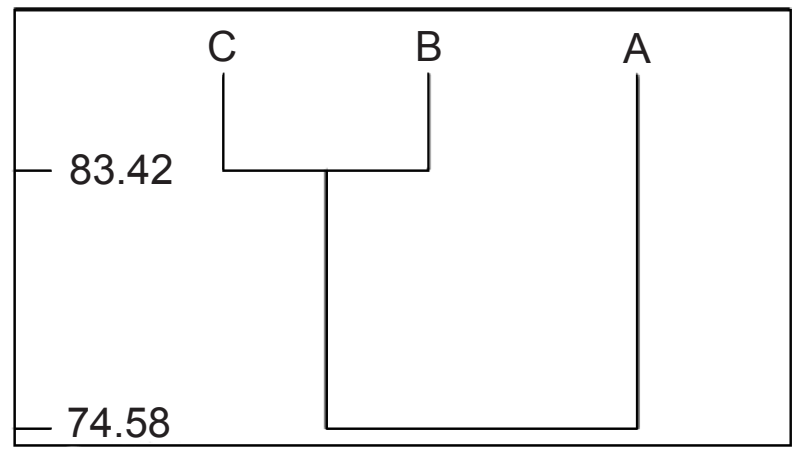

Fig. 1. Similarity dendrogram based on dominance indices of all mesostigmatid mites found in differently prepared basic belts $(\mathrm{A}=$ furrow with a ditch; $\mathrm{B}=$ no preparation; $\mathrm{C}=$ classic furrow)

Table 3. The impact of soil preparation method on the number of species per sample $(A=$ furrow with a ditch; $\mathrm{B}=$ no preparation; $\mathrm{C}=$ classic furrow)

Preparation method

$\begin{array}{ll}\text { A } & 3.1 \mathrm{a} \\ \text { B } & 3.0 \mathrm{a} \\ \text { C } & 3.0 \mathrm{a}\end{array}$

Average values marked with the same letters do not differ significantly $(P>0.05)$.

the experimental variants. The similarity rates of all mesostigmatid mites from the transverse belts (Fig. 2, Table 5) are more variable, between 45.14 and 83.57. The statistical analysis (Table 6) shows significant differences between the plots with respect to the dominance of mesostigmatids. The subplot where the residue was raked and removed differs considerably from the other plots with respect to species domi- 
Table 4. The impact of soil preparation method on the number of individuals per sample ( $\mathrm{A}=$ furrow with a ditch; $\mathrm{B}=$ no preparation; $\mathrm{C}=$ classic furrow)

Preparation method

Average number of individuals

\begin{tabular}{ll}
\hline A & $13.2 \mathrm{a}$ \\
B & $10.6 \mathrm{a}$ \\
C & $14.4 \mathrm{a}$ \\
\hline
\end{tabular}

Average values marked with the same letters do not differ significantly $(P>0.05)$.

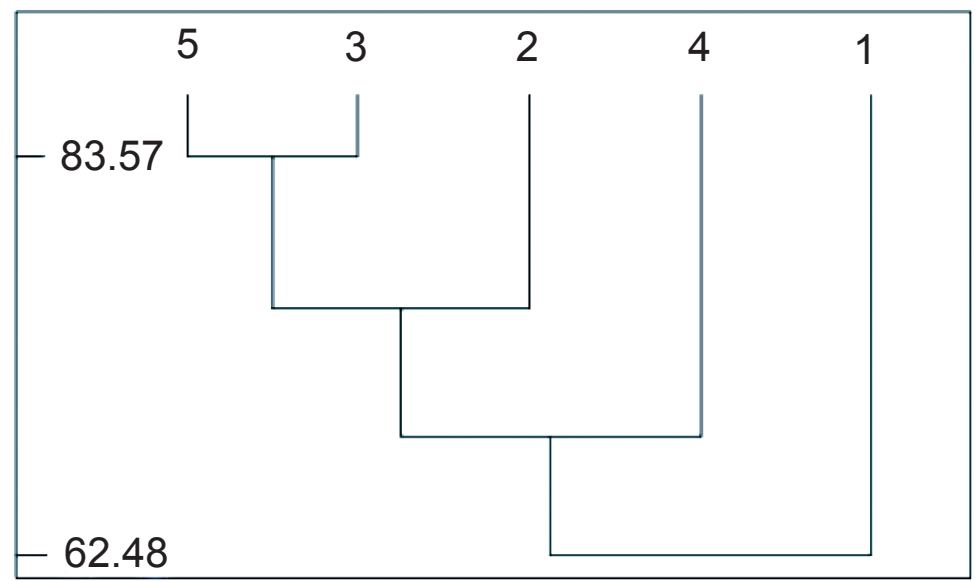

Fig. 2. Dendrogram of similarity rates of all mesostigmatid mites found in transverse belts with various methods of wood residue utilization $(1=$ raked and removed; $2=$ burnt; $3=$ left undisturbed; $4=$ chipped and left on the surface; $5=$ chipped and mixed with the soil)

nance. The highest similarity rate (83.56) concerns the subplot where the residue was chipped and mixed with the soil (3) and the subplot where the residue was left undisturbed (1). The wood residue utilization method also influenced the average number of species (the highest for belts 4 and 2, i.e. for grinding the residue and leaving it on the surface and for burning of the residue) (Table 6) and the average number of individuals per sample (definitely the highest for belt 4 , i.e. for grinding the residue and leaving it on the surface) (Table 7). 
Table 5. Similarity rates of mesostigmatid communities in transverse belts with various methods of wood residue utilization $(1=$ raked and removed; $2=$ burnt; $3=$ left undisturbed; $4=$ chipped and left on the surface; $5=$ chipped and mixed with the soil)

\begin{tabular}{ccccc}
\hline Transverse belts & 4 & 5 & 2 & 1 \\
\hline 3 & 63.137 & 83.566 & 75.504 & 48.722 \\
4 & & 68.780 & 57.526 & 45.135 \\
5 & & & 73.187 & 50.655 \\
2 & & & & 62.482 \\
\hline
\end{tabular}

Table 6. The impact of wood residue utilization method on the number of species per sample $(1=$ raked and removed; $2=$ burnt; $3=$ left undisturbed; $4=$ chipped and left on the surface; $5=$ chipped and mixed with the soil)

\begin{tabular}{cl}
\hline Utilization method & Average number of species \\
\hline 1 & $3.0 \mathrm{ab}$ \\
2 & $3.6 \mathrm{a}$ \\
3 & $3.0 \mathrm{ab}$ \\
4 & $3.9 \mathrm{a}$ \\
5 & $1.7 \mathrm{~b}$ \\
\hline
\end{tabular}

Average values marked with the same letters do not differ significantly $(P<0.01)$.

Table 7. The impact of wood residue utilization method on the number of individuals per sample $(1=$ raked and removed; $2=$ burnt; $3=$ left undisturbed; $4=$ chipped and left on the surface; $5=$ chipped and mixed with the soil)

\begin{tabular}{cc}
\hline Utilization method & Average number of individuals \\
\hline 1 & $9.4 \mathrm{~b}$ \\
2 & $14.6 \mathrm{ab}$ \\
3 & $12.3 \mathrm{ab}$ \\
4 & $20.3 \mathrm{a}$ \\
5 & $6.9 \mathrm{~b}$ \\
\hline
\end{tabular}

Average values marked with the same letters do not differ significantly $(P<0.01)$. 


\section{REFERENCES}

BŁaszak C., Madej G. 1997. Gamasida: Antennophorina, Microgyniina, Sejina, Gamasina. In: Wykaz zwierząt Polski (Razowski J., Ed), 4(4), pp. 190-202, Instytut Systematyki i Ewolucji Zwierząt PAN, Kraków.

Gornowicz R. 2005. Problematyka nowoczesnych technologii utylizacji pozostałości zrębowych [Technologies of clear-cut residue utilization methods on lowland]. Postępy Techniki w Leśnictwie, SITLiD DGLP, Warszawa 92: 7-12 (in Polish).

Kusiak W., Dymek-Kusiak A. 2002. The nature-economic monography of Puszcza Notecka forest. Wydawnictwo Przegląd Leśniczy, Poznań (in Polish).

Niedbąa W., BŁaszak C., BŁoszyk J., Kaliszewski M., Kaźmierski A. 1981. The mites (Acari). Fragm. Faun. 26: 105-156 (in Polish).

Odum E. 1982. Fundamentals of ecology, 2nd ed. PWRiL, Warszawa (in Polish).

Skorupski M., BŁaszczak P. 1998. Soil Mesostigmata (Acari) of 3 experimental Scots pine stands in the Gubin Forest District. Zesz. Nauk. ATR Bydgoszcz, Ochr. Środ. 2: 241-244.

Wiśniewski J. 1997. Uropodina. In: Wykaz zwierząt Polski (RAzowski J., Ed.), 4(4), pp. 202-205, Instytut Systematyki i Ewolucji Zwierząt PAN, Kraków.

Woś A. 1994. Klimat Niziny Wielkopolskiej [The climate of the Wielkopolska Lowland]. Wydawnictwo Naukowe UAM, Poznań (in Polish). 